\title{
Measuring Organizational Political Perceptions in Construction Industry Employees
}

\author{
A. Erkan Karaman (Corresponding author) \\ Faculty of Engineering, Department of Civil Engineering, Balikesir University, \\ Balikesir, Turkey \\ E-mail: ekaraman@baikesir.edu.tr \\ Tulay Civici \\ Faculty of Architecture, Department of Architecture, Balikesir University \\ Balıkesir, Turkey \\ E-mail: tulay@balikesir.edu.tr
}

\begin{abstract}
Although organizational politic behavior is present in every firm, it is often difficult to measure. The "Politics Perception Scale", developed by Kacmar and Ferris [1] in 1991, was used to measure the political behavior within the firm. The absence of such a research for construction sector employees is the starting point of this study. In this study, the perceptions of organizational politics encountered in construction sector employees were analyzed using the "Politics Perception Scale". Data on the items directed to the participants were collected by a questionnaire. Frequency distribution of measurement items was obtained and reliability analysis was made for the data. Graphical distributions of the items used in the measurement of the factors that constitute the perception of organizational politics scale (POPS) are presented. Correlation coefficients between factors were calculated by correlation analysis. The results showed that among the 5 factors that constitute the perception of organizational politics scale, the factor of "self-serving content" ranks first in organizational behavior.
\end{abstract}

Keywords: Organizational politics, political perception, construction firms.

DOI: $10.7176 / \mathrm{JSTR} / 6-11-04$

\section{Introduction}

Today, the concept of organizational politics is one of the controversial issues in many areas. A major research organization has examined the effects of organizational politics on organizational outcomes [2]. Organizational politics refers to "a social impact process, where behaviours are strategically designed to maximize short or long-term personal interests, despite the interests of others"[3]. Whether political behaviour is useful or harmful to companies depends on how this behaviour is perceived rather than the reality [4]. Cho and Yang [5] stated that organizational politics behaviours have significant impacts on the motivation of the employee and this is reflected in the employee's work performance.

Even though there is no doubt that domestic politics is a common phenomenon in every organization (e.g. [6]; [7]; [8]; [9]), little is known about the nature and limits of organizational politics ([10]; [11]; [13]). In the literature, there are two approaches dominating the discussions related to organizational politics. The first approach focuses on the impact tactics of employees in business life, which is the best indicator of political behaviour. Many studies have investigated possible causes and consequences for impact tactics, along with possible typologies ([11]; [13]; [14]; [15]; [16]). The second approach is relatively new and focuses on individual perceptions of organizational politics rather than political behaviour or impact tactics of the employees. According to Kacmar and Ferris [1] and Kacmar and Carlson [17], perception of organizational politics represents considering the work environments of the respondents as a political area in nature, interfering with the personal interests of others and thus the degree of individual injustice.

The literature review has shown that the concept of perceptions of organizational politics is not investigated for companies operating in the construction industry. In this study, a research was conducted for companies operating in the construction industry by benefiting from perceptions of

31 | P a g e

www.iiste.org 
organizational politics studies ([18]; [19]) carried out for different sectors.

\subsection{Organizational Politics}

Organizational politics are considered as a significant dimension of organizational functioning. Ferris et al. [20] defined organizational politics as behaviours strategically designed to maximize personal interests. However, most people think that this definition reflects the concept of organizational politics negatively. Mitzberg [6] suggested that organizational politics reflects illegitimate power relations between members of an organization. Gandz and Murray [4] stated that employees often see politics as unfair and abusive behaviours. Many studies ([21]; [22]; [23]; [24]; [25]) have focused on the "perceptions of organizational politics", in which organizational politics that reveals individual and organizational results is conceptualized negatively, and its relationship to negative policies.

According to various definitions in the literature, the political behaviours in the work place are actions that are not officially approved by the workplace and aim at achieving one's personal goals [26]. These political behaviours include personal gain, stabbing in the back (daggering), adulation, skipping the chain of orders for approval, lobbying higher levels for better job assignments or promotion or not sharing the necessary information with other employees. Here, it is important to stress that while similar political behaviour can often be ignored by the organization, these behaviours are not strictly prohibited in organizations [27]. In other words, the existence of political behaviours that are theoretically opposite to organizational policies can improve employees' perceptions of politics.

In this study, the "Perceptions of Organizational Politics Scale", which was developed by Kacmar and Ferris [1] and translated into Turkish by Erol [18], was applied to the construction sector employees. A total of 21 items were used to measure the factors. These factors are "Go Along To Get Ahead Content $\left(F_{1}\right)$ ", "Self-serving Content $\left(F_{2}\right)$ ", "Coworkers Content $\left(F_{3}\right)$ ", "Cliques Content $\left(F_{4}\right)$ " and "Pay and Promotion Content $\left(\mathrm{F}_{5}\right)$ ", respectively. The items used for measurement are given in Table 1.

\section{Research Methodology}

In order to measure perceptions of organizational politics of the employees working in the construction industry, a survey study titled "Perceptions of Organizational Politics Scale (POPS)" was conducted and the data were collected. The survey form used within the scope of this study was prepared in the light of the principles set by scientific research methods [28]. The evaluation of the survey was done with a five-point Likert scale ranging from "Strongly disagree" to "Strongly agree". The survey form titled "Perceptions of Organizational Politics in the Construction Industry" consists of 3 main sections and includes 25 questions. 4 of these 25 questions are categorical and 21 are Likert-type questions. The items (scales) used to collect the data required and measure the factors within the scope of the study were developed by adapting the scales, whose reliability has been tested in previous scientific studies (e.g. [18]), to the context of the construction industry.

The data obtained through the survey with 25 questions were carefully transferred to the computer. Frequency analysis related to the measurement items was performed with SPSS program. The distribution and average of the data received in regard with the measurement items were determined using the frequency analysis. The reliability analysis was carried out with the SPSS program in order to measure the reliability of the data collected. The perceptions of organizational politics of the employees working in the construction industry were tried to be measured by interpreting the responses of the respondents to each measurement item with the help of graphics. Finally, the correlation analysis was performed to determine whether there is a correlation between the factors that constitute the perceptions of organizational politics.

\section{Findings}

The sample of this study, which aims to examine the perceptions of organizational politics, was determined by considering the construction companies and projects (sector employees) operating within the province of Balikesir. Project managers, project directors, technical office managers, construction supervisors and engineers were identified as the target respondents of the research. After determination of the sample and target respondents, a total of 60 construction companies or construction projects that meet the specified criteria were contacted either by visiting or by telephone and e-mail. 47 respondents participated in the survey carried out within the scope of the study. Respondents filled out the entire two-page survey form, which was prepared in a clear format. The survey study aimed at measuring perceptions of organizational politics was evaluated in the light of the information received from 47 respondents.

32 | P a g e 
Table 1. Perceptions of organizational politics scale

\begin{tabular}{|c|c|c|}
\hline $\begin{array}{l}\text { Measurement } \\
\text { order }\end{array}$ & Factors & Items to measure factors \\
\hline 1. item & \multirow{6}{*}{$\begin{array}{l}\text { Go Along To Get } \\
\text { Ahead Content }\end{array}$} & $\begin{array}{l}\text { Those, who quitted the job, left the work place because they } \\
\text { realized that only hard work was not enough to get ahead. }\end{array}$ \\
\hline 2. item & & $\begin{array}{l}\text { In times of crisis and uncertainty, it is seen that those who get out } \\
\text { of the works evasively get ahead better. }\end{array}$ \\
\hline 3. item & & $\begin{array}{l}\text { There is no place for those who say "yes sir" to everything; It is } \\
\text { desirable to come up with good ideas even if it means } \\
\text { disagreement with the superiors. }\end{array}$ \\
\hline 4. item & & $\begin{array}{l}\text { Employees are encouraged to say their thoughts, even if their ideas } \\
\text { are criticized. }\end{array}$ \\
\hline 5. item & & $\begin{array}{l}\text { In our department, the people with higher performance get } \\
\text { promoted. }\end{array}$ \\
\hline 6. item & & The hard-working people receive the rewards. \\
\hline 7. item & \multirow{5}{*}{$\begin{array}{l}\text { Self-serving } \\
\text { Content }\end{array}$} & There are opposing groups that hinder productivity. \\
\hline 8. item & & $\begin{array}{l}\text { Most employees appear to have created rules to meet their needs } \\
\text { in cases, where the rules are not clear. }\end{array}$ \\
\hline 9. item & & $\begin{array}{l}\text { While the resources (budget, material, etc.) are distributed, the } \\
\text { saying "breasts are not given to a baby who does not cry" really } \\
\text { works. }\end{array}$ \\
\hline 10. item & & $\begin{array}{l}\text { Administrators use a selection system to hire people whose } \\
\text { perspectives are similar to them or who can help them in the } \\
\text { future. }\end{array}$ \\
\hline 11. item & & $\begin{array}{l}\text { The rules and policies regarding promotion and salary are fair, but } \\
\text { the way superiors implement these rules and policies is unfair. }\end{array}$ \\
\hline 12. item & \multirow{3}{*}{$\begin{array}{l}\text { Coworkers } \\
\text { Content }\end{array}$} & My colleagues do not help others. \\
\hline 13. item & & $\begin{array}{l}\text { If a colleague offers you help, he will do so not because he really } \\
\text { cares about you, but because he is expecting something from you } \\
\text { in return. }\end{array}$ \\
\hline 14. item & & $\begin{array}{l}\text { When my superior (supervisor) communicates with me, his } \\
\text { purpose is not to help me, but to show himself better to other in } \\
\text { the work place. }\end{array}$ \\
\hline 15. item & \multirow{4}{*}{ Cliques Content } & A new recruiter soon learns who to get along with. \\
\hline 16. item & & You can get what you want if you have a man. \\
\hline 17. item & & $\begin{array}{l}\text { There have been influential groups that no one can afford to } \\
\text { oppose. }\end{array}$ \\
\hline 18. item & & $\begin{array}{l}\text { Regardless of the quality of the work you do, you can get on with } \\
\text { your business by getting on well with everyone. }\end{array}$ \\
\hline 19. item & \multirow{3}{*}{$\begin{array}{l}\text { Pay and } \\
\text { Promotion } \\
\text { Content }\end{array}$} & Salary and promotion policies are reported to employees. \\
\hline 20. item & & $\begin{array}{l}\text { Rules and policies regarding promotion and salary are clearly } \\
\text { defined. }\end{array}$ \\
\hline 21. item & & $\begin{array}{l}\text { Bilateral relations, rather than the quality and amount of the work } \\
\text { done, are effective in salary and promotion. }\end{array}$ \\
\hline
\end{tabular}

The age range of the respondents participated in the research is given in Figure 1. Considering the data given in Figure 1, 6.4\% of the participants are " $20-25$ ", $44.7 \%$ are " $26-30$ ", $10.6 \%$ are " $31-35$ ", $19.1 \%$ are " $36-40 ", 10.6 \%$ are " $41-45$ ", $4.3 \%$ are in the " $46-50$ " and $4.3 \%$ are in the " 51 and over" age range, respectively. The answers given in response to the question "Do you feel that you are working in a corporate company?" are shown in Figure 2. $87 \%$ of the respondents consider themselves working in a corporate company, while the remaining $13 \%$ do not feel this way. 


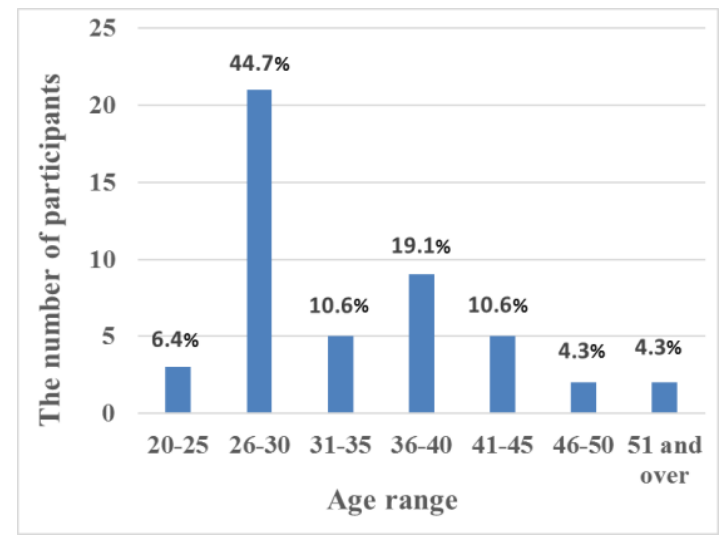

Figure 1. Age range of the respondents

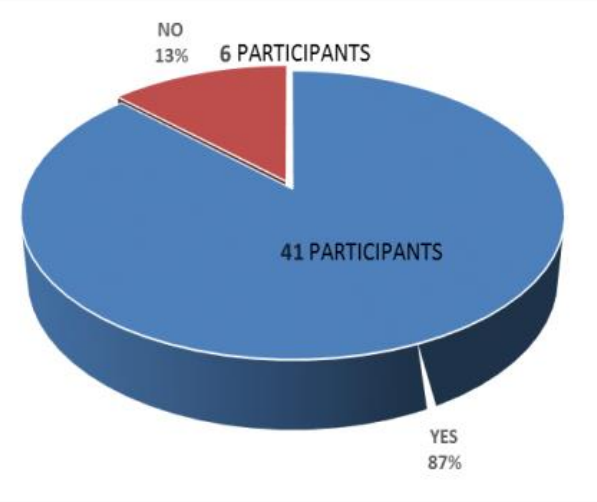

Figure 2. Do you feel as working in a corporate company?

The answers given in response to the question "Did you get benefits by using your bilateral relations in the workplace?" are shown in Figure 3. 89\% of the respondents stated that they did not try to have any benefits, while the remaining $11 \%$ stated that they obtained benefits by using their bilateral relations. Finally, the answers given in response to the question whether the respondents are always honest at the workplace are shown in Figure 4. 72\% of the respondents stated that "yes, I am acting honestly", while the remaining $28 \%$ stated that "I am not acting honestly".

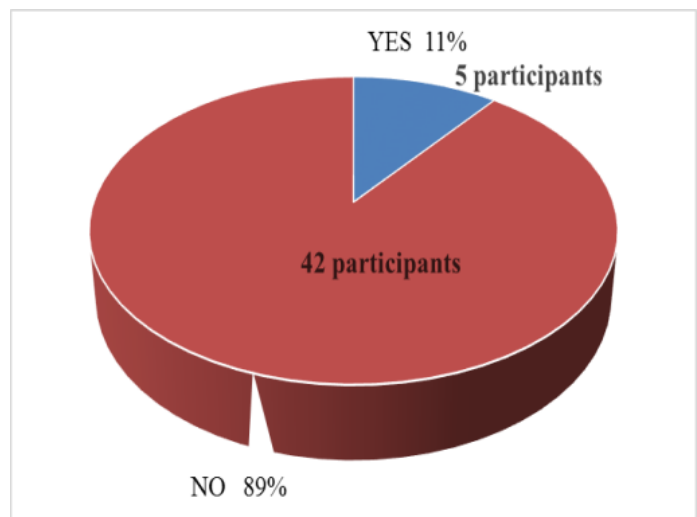

Figure 3. Did you get benefits by using your bilateral honestly elations in the workplace? 


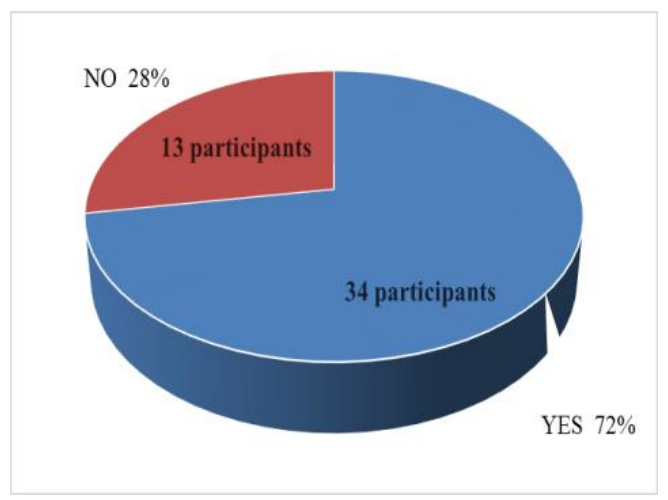

Figure 4. Do you think that you always act at the work place?

The distribution of the data obtained related to the items given in the Likert scale as a result of the frequency analysis is given in Table 2. In the measurement performed with the Likert scale, the item "you can get what you want if you have a man" received the highest number of responses, which is "I strongly agree" by 18 respondents. On the other hand, the item "my colleagues do not help others" received the highest number of responses, which is "I strongly disagree" by 6 respondents.

The Perceptions of Organizational Politics Scale (POPS) developed by Kacmar and Ferris [1] consists of five subscales (factors). A total of 21 items were presented to the respondents for the measurement of each factor. It is statistically important to measure whether the data obtained from the respondents are reliable or not. Reliability analyses of the data obtained were performed with the help of SPSS program. Reliability analysis is performed in order to determine the consistency of the questions included in the scale. Cronbach's alpha $(\alpha)$ values obtained from reliability analysis, and mean and standard deviation values related to factors are given in Table 3.

Cronbach's alpha $(\alpha)$ value is a weight standard change mean found by proportioning the sum of variances of the questions in the example to the general variance. A Cronbach's alpha $(\alpha)$ value of 0.70 and above means that the questions in that group will be considered reliable [29]. Since the Cronbach's alpha value of all factors given in Table 3 is greater than 0.70 , the measurement performed is statistically reliable.

At this stage of the study, the distribution of the items used for the measurement of each factor and the means of the factors are presented in Figure 5. The average of 6 items regarding the "Go Along To Get Ahead Content" factor was found to be 3.199. The $2^{\text {nd }}$ and $5^{\text {th }}$ items received the highest value (3.489), while the $1^{\text {st }}$ item received the lowest value. Considering the "Self-serving Content" factor, $9^{\text {th }}$ item received the highest value (4.106), while the $11^{\text {th }}$ item received the lowest value $(3.683)$, and the average of the factor was found to be 3.889 . The average of "Coworkers Content" factor was found to be 3.135 , while the $13^{\text {th }}$ item received the highest value $(3.255)$ and the $12^{\text {th }}$ item received the lowest value (3.00), respectively. The average of "Cliques Content" factor was found to be 3.638 , while the $16^{\text {th }}$ item received the highest value (3.979) and the $18^{\text {th }}$ item received the lowest value (3.298). At last, the "Pay and Promotion Content" factor was measured by $19^{\text {th }}, 20^{\text {th }}$ and $21^{\text {st }}$ items, and the $21^{\text {st }}$ item received the highest value $(3.511)$ and the $20^{\text {th }}$ item received the lowest value $(3.340)$. The average of the measured factors was found to be 3.433 . 
International Journal of Scientific and Technological Research

ISSN 2422-8702 (Online), DOI: 10.7176/JSTR/6-11-04

Vol.6, No.11, 2020

Table 2. Frequency distribution of measurement items

\begin{tabular}{|c|c|c|c|c|c|c|c|c|c|c|c|}
\hline \multirow{2}{*}{$\begin{array}{l}\text { Questionnaire } \\
\text { Items }\end{array}$} & \multicolumn{2}{|c|}{$\begin{array}{l}\text { Strongly } \\
\text { Disagree }\end{array}$} & \multicolumn{2}{|c|}{ Disagree } & \multicolumn{2}{|c|}{$\begin{array}{c}\text { Not } \\
\text { Decided }\end{array}$} & \multicolumn{2}{|c|}{ Agree } & \multicolumn{2}{|c|}{$\begin{array}{l}\text { Strongly } \\
\text { Agree }\end{array}$} & \multirow{2}{*}{ Average } \\
\hline & $\mathrm{f}$ & $\%$ & $\mathrm{f}$ & $\%$ & $\mathrm{f}$ & $\%$ & $\mathrm{f}$ & $\%$ & $\mathrm{f}$ & $\%$ & \\
\hline 1 & 4 & 8.5 & 16 & 34.0 & 14 & 29.8 & 12 & 25.5 & 1 & 2.1 & 2.787 \\
\hline 2 & 1 & 2.1 & 11 & 23.4 & 7 & 14.9 & 20 & 42.6 & 8 & 17.0 & 3.489 \\
\hline 3 & 2 & 4.3 & 12 & 25.5 & 15 & 31.9 & 14 & 29.8 & 4 & 8.5 & 3.128 \\
\hline 4 & 2 & 4.3 & 17 & 36.2 & 9 & 19.1 & 14 & 29.8 & 5 & 10.6 & 3.064 \\
\hline 5 & 1 & 2.1 & 6 & 12.8 & 14 & 29.8 & 21 & 44.7 & 5 & 10.6 & 3.489 \\
\hline 6 & 0 & 0 & 15 & 31.9 & 10 & 21.3 & 18 & 38.3 & 4 & 8.5 & 3.234 \\
\hline 7 & 0 & 0 & 5 & 10.6 & 9 & 19.1 & 26 & 53.3 & 7 & 14.9 & 3.745 \\
\hline 8 & 2 & 4.3 & 3 & 6.4 & 1 & 2.1 & 27 & 57.4 & 14 & 29.8 & 4.021 \\
\hline 9 & 1 & 2.1 & 2 & 4.3 & 5 & 10.6 & 22 & 46.8 & 17 & 36.2 & 4.106 \\
\hline 10 & 1 & 2.1 & 3 & 6.4 & 6 & 12.8 & 23 & 48.9 & 14 & 29.8 & 3.979 \\
\hline 11 & 2 & 4.3 & 7 & 14.9 & 8 & 17.0 & 19 & 40.4 & 11 & 23.4 & 3.683 \\
\hline 12 & 6 & 12.8 & 14 & 29.8 & 9 & 19.1 & 10 & 21.3 & 8 & 17.0 & 3.000 \\
\hline 13 & 4 & 8.5 & 13 & 27.7 & 8 & 17.0 & 11 & 23.4 & 11 & 23.4 & 3.255 \\
\hline 14 & 2 & 4.3 & 14 & 29.8 & 11 & 23.3 & 15 & 31.9 & 5 & 10.6 & 3.149 \\
\hline 15 & 2 & 4.3 & 5 & 10.6 & 8 & 17.0 & 20 & 42.6 & 12 & 25.5 & 3.745 \\
\hline 16 & 2 & 4.3 & 5 & 10.6 & 3 & 6.4 & 19 & 40.4 & 18 & 38.3 & 3.979 \\
\hline 17 & 1 & 2.1 & 9 & 19.1 & 7 & 14.9 & 24 & 51.1 & 6 & 12.8 & 3.532 \\
\hline 18 & 2 & 4.3 & 13 & 27.7 & 7 & 14.9 & 19 & 40.4 & 6 & 12.8 & 3.298 \\
\hline 19 & 4 & 8.5 & 9 & 19.1 & 5 & 10.6 & 20 & 42.6 & 9 & 19.1 & 3.447 \\
\hline 20 & 5 & 10.6 & 10 & 21.3 & 4 & 8.5 & 20 & 42.6 & 8 & 17.0 & 3.340 \\
\hline 21 & 1 & 2.1 & 10 & 21.3 & 8 & 17.0 & 20 & 42.6 & 8 & 17.0 & 3.511 \\
\hline
\end{tabular}



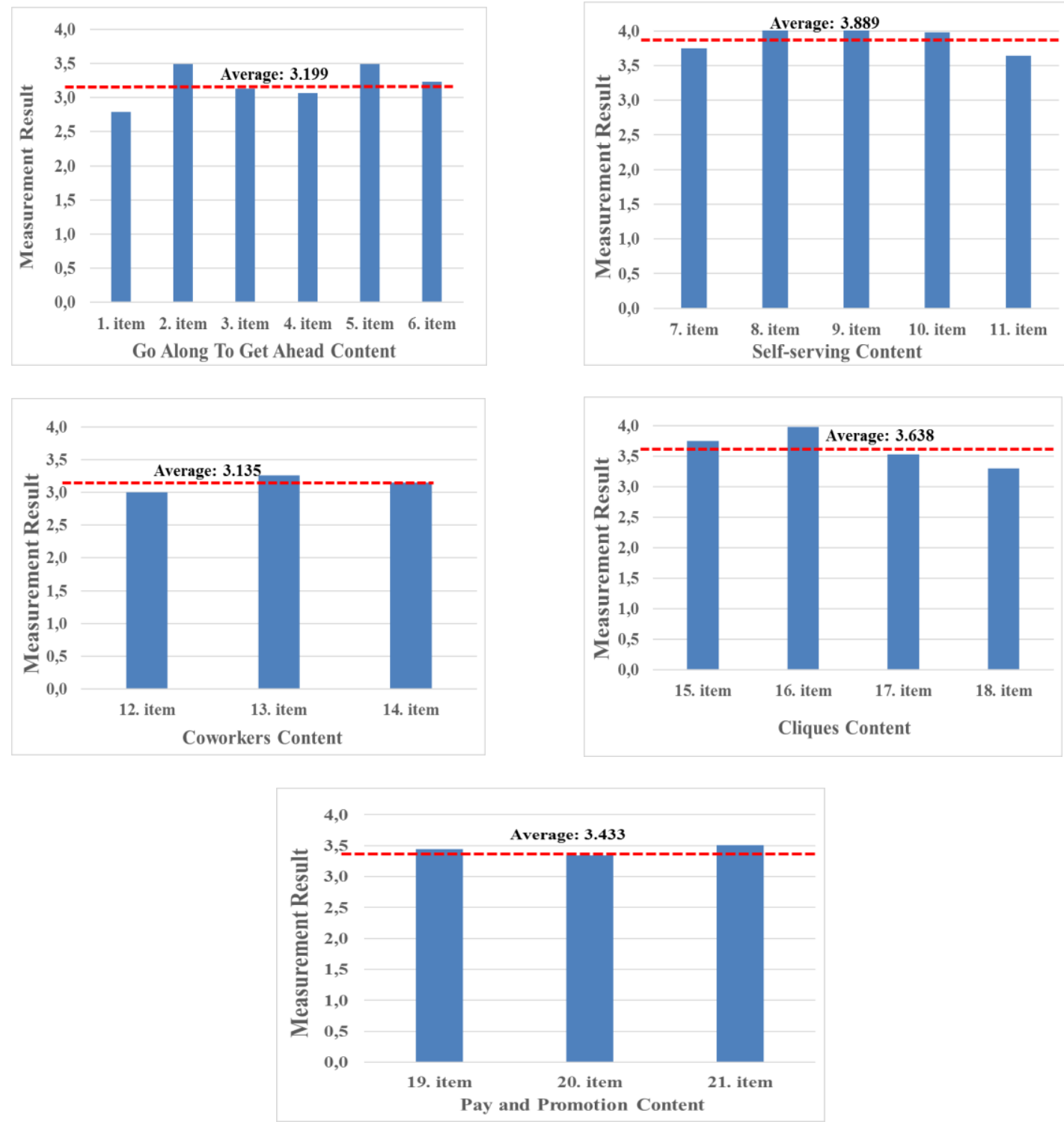

Figure 5. Distribution of the statements used to measure the factors

Table 3. Standard deviations of factors $(\sigma)$ and Cronbach's alpha $(\alpha)$ values

\begin{tabular}{ll|ccc}
\hline \hline FACTORS & & $\begin{array}{c}\text { Number of } \\
\text { Questions }\end{array}$ & $\begin{array}{c}\text { Standard } \\
\text { Deviation }(\sigma)\end{array}$ & $\begin{array}{c}\text { Cronbach's } \\
\text { alfa }(\alpha)\end{array}$ \\
\hline Go Along To Get Ahead Content & $\left(\mathrm{F}_{1}\right)$ & 6 & 0.667 & 0.719 \\
Self-serving Content & $\left(\mathrm{F}_{2}\right)$ & 5 & 0.700 & 0.771 \\
Coworkers Content & $\left(\mathrm{F}_{3}\right)$ & 3 & 1.122 & 0.876 \\
Cliques Content & $\left(\mathrm{F}_{4}\right)$ & 4 & 0.835 & 0.758 \\
Pay and Promotion Content & $\left(\mathrm{F}_{5}\right)$ & 3 & 1.033 & 0.796 \\
\hline
\end{tabular}


In the final stage of the study, the correlation analysis presented in Table 4 was performed in order to determine the correlation between the factors. Correlation analysis is a statistical method used to determine whether there is a linear relationship between two numerical measurements; if any, the direction and severity of this relationship. If the data has a normal distribution, the Pearson correlation coefficient is preferred; however, if the data is not normally distributed, the Spearman Rank correlation coefficient is preferred. Pearson correlation coefficient was used in the analysis as the survey data showed normal distribution. If the correlation coefficient is negative, there is an inverse relationship between the two factors. In other words, one of the factors increases, while the other decreases. If the correlation coefficient is positive, it is interpreted that "one factor increases while the other increases". If the correlation value is less than 0.2 , then the correlation between the factors is considered to be "very weak", if it is between 0.2 and 0.4 , the correlation is "weak", if it is between 0.4 and 0.6 , the correlation is "moderate", if it is between 0.6 and 0.8 , the correlation is "high" and if it is greater than 0.8 , the correlation is considered to be "very high", respectively. Considering the data given in Table 4, the correlation coefficients of five different matches were found to be statistically significant. All of the correlation coefficients, which were found to be significant, were also positive.

Table 4. Correlation values of the factors with each other

\begin{tabular}{|c|c|c|c|c|c|c|}
\hline & & $\mathrm{V}_{1}$ & $\mathrm{~V}_{2}$ & $\mathrm{~V}_{3}$ & $\mathrm{~V}_{4}$ & $\mathrm{~V}_{5}$ \\
\hline \multirow{2}{*}{$\mathrm{F}_{1}$} & Pearson Correlation & \multirow{2}{*}{1} & $0.317^{*}$ & $0.281^{*}$ & 0.131 & $0.292^{*}$ \\
\hline & Sig. & & 0.030 & 0.049 & 0.379 & 0.046 \\
\hline \multirow{2}{*}{$\mathrm{F}_{2}$} & Pearson Correlation & $0.317^{*}$ & \multirow{2}{*}{1} & 0.116 & 0.043 & $0.473^{* *}$ \\
\hline & Sig. & 0.030 & & 0.438 & 0.772 & 0.001 \\
\hline \multirow{2}{*}{$\mathrm{F}_{3}$} & Pearson Correlation & $0.281^{*}$ & 0.116 & \multirow{2}{*}{1} & $0.334^{*}$ & 0.213 \\
\hline & Sig. & 0.049 & 0.438 & & 0.022 & 0.151 \\
\hline \multirow{2}{*}{$\mathrm{F}_{4}$} & Pearson Correlation & 0.131 & 0.043 & $0.334^{*}$ & \multirow{2}{*}{1} & 0.213 \\
\hline & Sig. & 0.379 & 0.772 & 0.022 & & 0.151 \\
\hline \multirow{2}{*}{$\mathrm{F}_{5}$} & Pearson Correlation & $0.292^{*}$ & $0.473^{* *}$ & 0.213 & 0.252 & \multirow{2}{*}{1} \\
\hline & Sig. & 0.046 & 0.001 & 0.151 & 0.087 & \\
\hline
\end{tabular}

\section{Conclusions}

This study aims to examine the perceptions of organizational politics of technical personnel working in the construction companies or projects within the province of Balkesir by using the "Perceptions of Organizational Politics Scale" developed by Kacmar and Ferris [1]. Considering both the number of construction firms and their projects in Balıkesir and the epidemic disease period, the data obtained from the 47 respondents through the survey is very valuable despite the fact that it is limited.

Considering the findings of the study, it is seen that the age of $80.8 \%$ of the respondents is 40 years and under. This shows that data has been collected from a group of young employees. The number of people considering themselves as working in a corporate firm is remarkable. This can be explained by the facts that the city of Balkesir offers a comfortable working environment, and the low workload and small number of employees of the companies provide a sense of belonging to the employees. For similar reasons, the respondents are more transparent and honest in their bilateral relations.

When the findings obtained from the evaluation of the 5 factors that constitute the Perceptions of Organizational Politics Scale are evaluated, "Self-serving Content" factor takes the first place, followed by "Cliques Content", "Pay and Promotion Content" and "Go Along To Get Ahead Content" factors, respectively. "Coworkers Content" factor takes the last place. It is surprising to see that the average of the factor findings that constitute the Perceptions of Organizational Politics Scale of the respondents, who say that they are mostly honest and transparent in bilateral relations, is above 3.00 . In the correlation analysis regarding the factors, the highest correlation coefficient was obtained between "Pay and Promotion Content" and "Self-serving Content" factors. Although the correlation coefficients between the 5 factors that were statistically significant were low, the changes in the factors were in the same direction since the correlation coefficients between these factors are positive. 


\section{References}

[1] Kacmar K.M., Ferris G.R., Perceptions of Organizational Politics Scale (POPS): Development and construct validation. Educational and Psychological Measurement, 51 (1), 193-205, 1991.

[2] Ferris, G. R., Adams, G., Kolodinsky, R. W., Hochwarter, W. A., Ammeter, A. P., Perceptions of organizational politics: Theory and research directions. In F. J. Yammarino, \& F. Dansereau (Eds.), Research in multi-level issues (Vol. 1, pp. 179e254). Oxford: JAI Press/Elsevier Science, 2002.

[3] Ferris, G. R., Fedor, D. B., Chachere, J. G., Pondy, L. R., Myths and politics in organizational contexts. Group and Organization Studies, 14, 83-103, 1983.

[4] Gandz, J., Murray, V. (1980) The experience of workplace politics. Academy of Management Journal, 23, 237-251.

[5] Cho, H. T., Yang, J. S. , How perceptions of organizational politics influence self-determined motivation: The mediating role of work mood. Asia Pacific Management Review, 23, 60-69, 2018.

[6] Mintzberg H., Power in and around organizations Englewood Cliffs, NJ: Prentice-Hall, 1983.

[7] Ferris G.R., King T.R., Politics in human resources decisions: a walk on the dark side, Organ Dyn;20:59-71, 1991.

[8] Pfeffer J., Management with power Boston, MA: Harvard Business School Press, 1992.

[9] Zhou J, Ferris GR. (1995) The dimensions and consequences of organizational politics perceptions: a confirmatory analysis. J Appl Soc Psychol, 25:1747-64.

[10] Mayes B.T., Allen R.W., Toward a definition of organizational politics. Acad Manage Rev, 2:672-8, 1977 .

[11] Kipnis D, Schmidt SM, Wilkinson I. (1980) Intraorganizational influence tactics: exploration in getting one's way, J Appl Psychol, 65:440- 52.

[12] Cropanzano R, Howes JC, Grandey AA, Toth P. (1997) The relationship of organizational politics and support to work behaviors, attitudes, and stress, J Organ Behav, 18:159-80.

[13] Burns T., Micropolitics: mechanisms of institutional change, Adm Sci Q, 6:257 - 81, 1961.

[14] Izraeli D., The middle manager and the tactics of power expansion: a case study, Sloan Manage Rev, 16:57-70, 1975.

[15] Izraeli D. (1987) Sex effects in the evaluation of influence tactics, J Occup Behav, 8:79- 86.

[16] Brass DJ. (1984) Being in the right place: a structural analysis of individual influence in an organization, Adm Sci, 29:518-39.

[17] Kacmar KM, Carlson DS., Further validation of the perceptions of politics scale (POPS): a multiple sample investigation,. Paper presented at the annual meeting of the Academy of Management, Dallas, Texas, 1994. 
[18] Erol, E., Perceptions of Organizational Politics Scale (POPS) Questionnaire into Turkish: A Validity and Reliability Study (Örgütsel Politika Algı Ölçeğinin (POPS) Türkçe Uyarlaması: Geçerlik ve Güvenirlik Çalışması), International Journal of Assessment Tools in Education (IJATE), 2 (1), 58 - 78, 2015.

[19] Malik, O. F., Shahzad, A., Raziq, M. M., Khan, M. M., Yusaf, S., \& Khan, A., Perceptions of organizational politics, knowledge hiding, and employee creativity: The moderating role of professional commitment, Personality and Individual Differences, 142, 232-237, 2019.

[20] Ferris GR, Russ GS, Fandt PM., Politics in organizations. In: Giacalone RA, Rosenfeld P, editors. Impression management in the organization. Hillsdale, NJ: Lawrence Erlbaum, pp. 143$70,1989$.

[21] Medison, L. M., Allen, R. W., Porter, L. W., Renwick, P. A., \& Mayes, B. T., Organizational politics: An exploration of managers' perceptions. Human Relations, 33, 79-100, 1980.

[22] Block P., The empowered manager: positive political skills at work San Francisco, JosseyBass, 1988.

[23] Ferris G.R, Kacmar K.M. (1992) Perceptions of organizational politics, J Manage, 18:93- 116.

[24] Drory A., Perceived political climate and job attitudes, Organ Stud, 14:59-71, 1993.

[25] Vigoda, E., Internal politics in public administration systems: An empirical examination of its relationship with job congruence, organizational citizenship behavior, and in-role performance, Public Personnel Management, 29, 185-210, 2000.

[26] Poon, J.M.L., Effects of performance appraisal politics on job satisfaction and turnover intention, Personal Review, 33(3), 322-334, 2004.

[27] Yilmaz, O. D. (2014) Perception of organizational politics and impression management behaviors: A tourism industry perspective, International Journal of Business and Social Science, Vol. 5, No. 8.

[28] Kinnear, T.C. and Taylor, J.R., Marketing research: an applied approach, fourth edition, McGraw-Hill, Singapore, 2012.

[29] Nunally J. C., Psychometric theory (2nd edition). McGraw-Hill, New York, 1978. 